\title{
Petrology and geochemistry of the ultrapotassic alkaline intrusives from the Damodar valley, eastern Indian shield necessitate revision in the IUGS classification of mafic ultrapotassic alkaline rocks
}

\author{
Rajesh K. Srivastava ${ }^{a}$, N. V. Chalapathi Raob, Anup K. Sinha and Rajeev L. Bharati \\ Igneous Petrology Laboratory, Department of Geology, Banaras Hindu University, Varanasi 221 005, \\ India (Email addresses: ${ }^{a}$ rajeshgeolbhu@yahoo.com, ${ }^{b}$ nvcr100@gmail.com)
}

Widespread Cretaceous potassic alkaline rocks manifested in the Damodar valley \{also known as Damodar valley alkaline igneous rocks (DAIR) $\}$ of the Eastern Indian shield are well acknowledged for their petrographic and geochemical diversity. Yet, they remain a 'Pandora's box of petrological confusion' (Mitchell, 2007) with a variety of exotic, and potentially diamondiferous rocks such as lamprophyre, lamproite, orangeite and kimberlite being continuously reported from them over one century or more. The prevailing confusion is due to an interplay of (i) lack of systematic studies involving random collection of samples in a wide-spread area and (ii) nonconsideration of mineralogical-genetic classification schemes. Recent studies elsewhere have also emphasized the importance of integration of geochemistry and petrological studies in alkaline rock nomenclature and genesis (e.g. Tappe et al., 2006). In order to address these highly contentious, yet very important, issues we have initiated a systematic and comprehensive study on the alkaline intrusives from distinct domains in the Damodar valley. This paper confines to the results obtained on samples collected from the Jharia area in the Damodar Valley and debates on the genesis of Jharia alkaline igneous rocks (JAIR), as to whether (i) they are enriched pockets of subcontinental lithosphere that melted upon by the impact by Kerguelen mantle plume on the Eastern Indian shield or (ii) they represent a predominantly plumederived components.

E-W trending Damodar valley is located in the Chhotangapur Gneiss Granulite Complex (CGGC) of the northern Singhbum craton and hosts major Gondwana coal fields such as Ranigunj, Jharia, Bokaro, Karanpura and Daltongunj (Fig. 1). Sarkar et al. (1980) dated DAIRs to be of 105-121Ma using conventional K-Ar dating technique, whereas Kent et al. (1998) obtained ${ }^{40} \mathrm{Ar} /{ }^{39} \mathrm{Ar}$ age of $\sim 116$ Ma using laser dating techniques on DAIRs from Jharia area. Thus, the emplacement of the DAIRs is almost contemporaneous with the Rajmahal basalt volcanism at $117 \pm 2 \mathrm{Ma}$.

All the studied rocks from the JAIR share similar mineralogy with widely varying modal proportions of

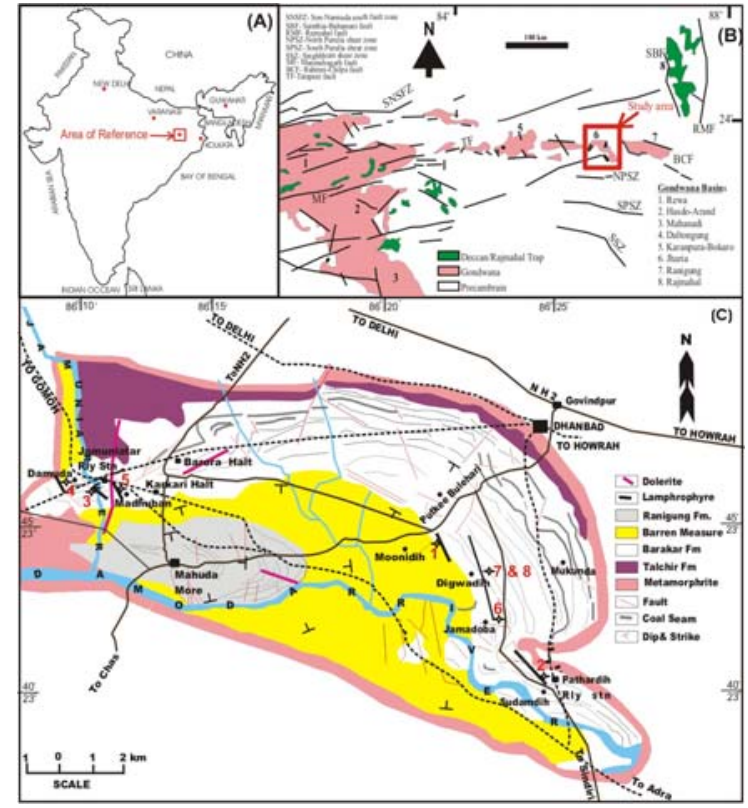

Fig. 1 Location and geological map of the JAIR.

olivine, phlogopite, clinopyroxene, amphibole, Kfeldspar, apatite, carbonates, rutile, pyrite, Mgilmenite, talc, chlorite, quartz and opaque minerals. Olivine, phlogopite and carbonate are the predominant phases. Apatite and rutile constitute the important accessories. Most samples show porphyritic textures rest others display fine-grained textures.

Total alkalis and silica composition of the JAIR samples essentially plot them in the alkaline field. Distinct alkaline trait of the JAIR is also attested by the presence of one or more minerals of nepheline, leucite and olivine in the CIPW norm. High Mg\# ranging from 72-83 indicate their primitive nature. All of them are essentially ultrapotassic $\left(\mathrm{K}_{2} \mathrm{O} / \mathrm{Na}_{2} \mathrm{O}: 8-107\right)$ and ultramafic (MgO:4.88-16.94 wt\%). High $\mathrm{TiO}_{2}$ (3.85-7.23 wt\%) as well as high $\mathrm{P}_{2} \mathrm{O}_{5}$ (1.47-5.04 wt\%) contents are key features of these rocks owing to high modal rutile + ilmenite and apatite respectively. Diferentiation trends observed on geochemical variation digrams are inferred to be primary trends; 


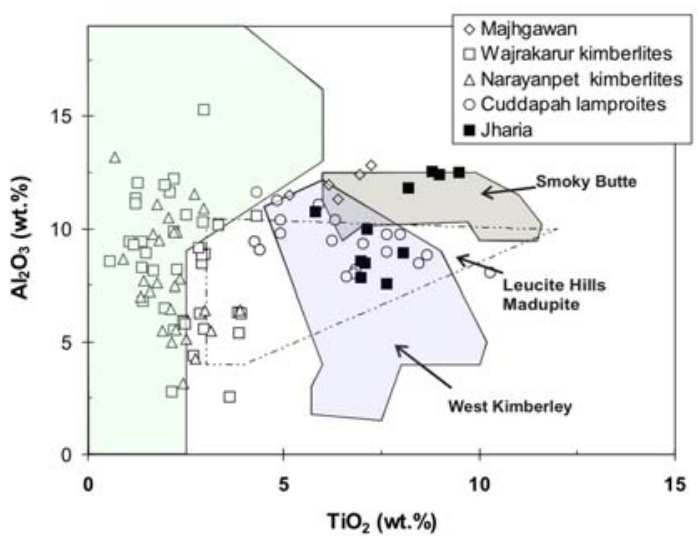

Fig. $2 \mathrm{TiO}_{2}-\mathrm{Al}_{2} \mathrm{O}_{3}$ plot for phlogopite from JAIR .

they also imply that majority of the carbonates present in the sample could well be of primary origin. EPMA studies reveal that the JAIR phlogopite exhibit widerange in composition in terms of its $\mathrm{TiO}_{2}$ (5.82-9.48 wt\%), $\mathrm{Al}_{2} \mathrm{O}_{3}$ (7.54-12.54 wt\%) and $\mathrm{FeO}_{\mathrm{T}}(4.38-13.11$ wt\%) contents and occupy fields similar to those of Cuddapah lamproites of Dharwar craton, Smoky Butte and Leucite Hills lamproites of U.S.A. with respect to titania content (Fig. 2).

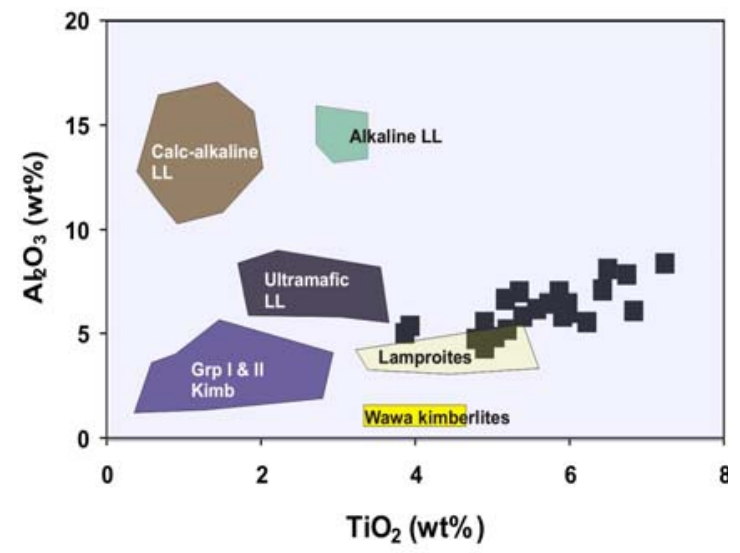

Fig. $3 \mathrm{TiO}_{2}-\mathrm{Al}_{2} \mathrm{O}_{3}$ (wt\%) plot for JAIR whole-rock (fields after Lefebvre et al. 2005).

In $\mathrm{Al}_{2} \mathrm{O}_{3}$ vs $\mathrm{TiO}_{2}$ plot (Fig.3), involving what are considered to be least mobile of the major elements during alteration, and in $\mathrm{MgO}$ vs $\mathrm{SiO}_{2}$ plot (Fig.4), which are the best illustrators of magmatic differentiation, JAIR samples display strong affinities towards the lamproite and ultramafic lamprophyre fields.

Chondrite-normalized REE patterns (Fig. 5) of JAIR are highly fractionated $(\mathrm{La} / \mathrm{Yb}=65-142)$ and enriched in LREE than HREE. JAIR have LREE as well as HREE contents are appreciably higher than those of diamondiferous kimberlites from the Wajrakarur, Dharwar craton, southern India thereby possibly implying a relatively much metasomatised (enriched) but less depleted (shallower) mantle source regions.

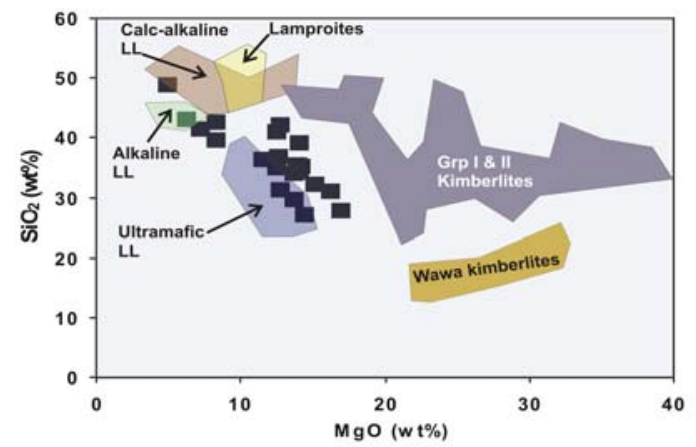

Fig.4 $\mathrm{MgO}-\mathrm{SiO}_{2}$ (wt\%) plot for JAIR whole-rock (fields after Lefebvre et al. 2005)

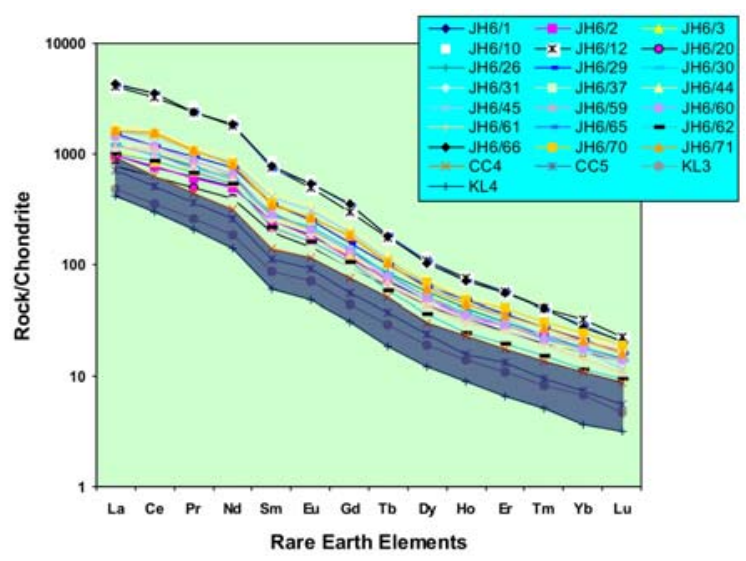

Fig. 5 Chondrite normalized REE patterns for JAIR

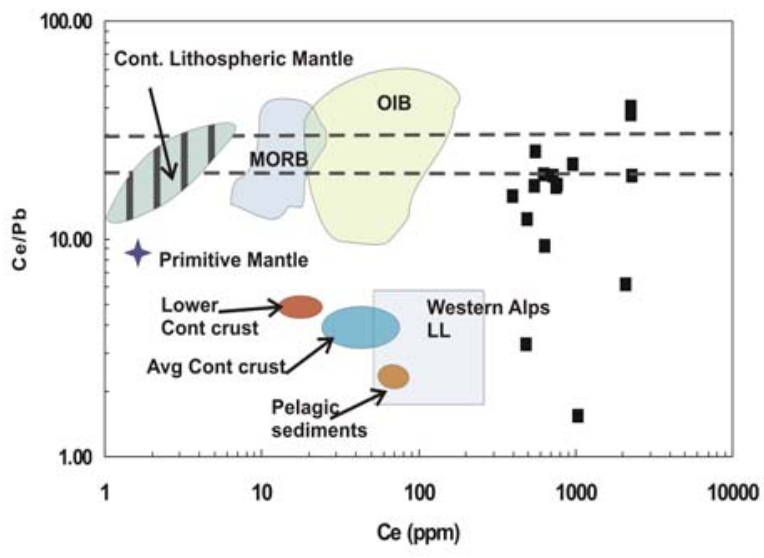

Fig. $6 \mathrm{Ce}-\mathrm{Ce} / \mathrm{Pb}$ plot for JAIR. Fields are from Owen (2007).

$\mathrm{Ce} / \mathrm{Pb}$ (Fig.6) ratios of JAIR show that their their $\mathrm{Ce}$ and $\mathrm{Nb}$ contents are several times enriched than a MORB or OIB or even 'normal' continental lithospheric mantle. A considerable range is displayed by JAIR and some of data also straddle around field of pelagic sediments and Western Alps lamprophyres that are subduction related. This also imply source heterogeneity.

Extreme silica undersaturation, moderately Mg-nature, acute impoverishment of $\mathrm{Na}$, $\mathrm{Al}$ depletion, strong $\mathrm{Ca}$ enrichment, high $\mathrm{K}$ nature, elevated Ti and pronounced 
P content displayed by the JAIR are not characteristic of archetypal kimberlite, lamproite and orangeite but are hall mark of aillikite rocks - a variety of ultramafic lamprophyres (Tappe et al., 2006). Various geochemical discrimination diagrams and compatible and incompatible elemental ratios of the JAIR carried out in this study also demonstrate marked similarity to aillikites along with some affinities towards lamproites. Combined modal mineralogy and chemical composition of the JAIR render them 'difficult to classify’ rock types. The existing IUGS systems of classification schemes (Le Maitre, 2002) for alkaline potassic rocks are inadequate to pigeon-hole the nomenclature of JAIR. We would prefer to term them as alkaline potassic intrusives with affinities to aillikites, lamproites and orangeites.

Low degrees of partial melting of carbonate-bearing garnet lherzolite can account high concentration of incompatible elements, high LREE/HREE and low $\mathrm{Al}_{2} \mathrm{O}_{3}$ abundances as seen in JAIR samples. On $\mathrm{Zr} / \mathrm{Hf}$ vs $\mathrm{Nb} / \mathrm{Ta}$ plot (Fig. 7) most of the JAIR samples have higher $\mathrm{Zr} / \mathrm{Hf}$ ratios than that of a OIB, MORB and PM and suggest enrichment of source regions by carbonaterich melts.

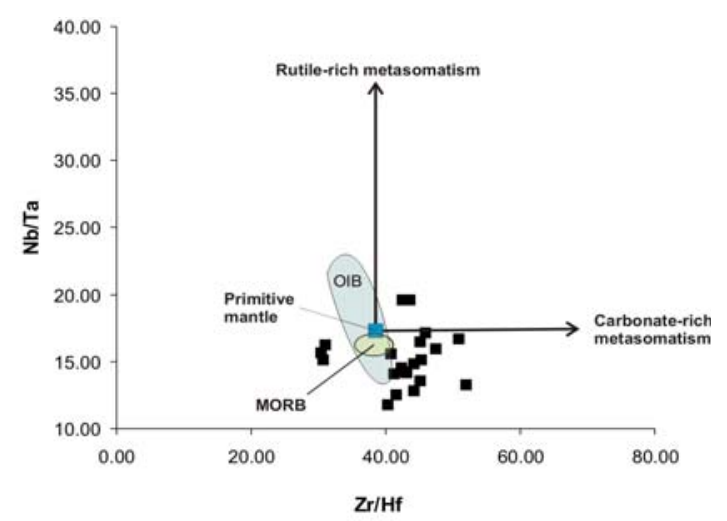

Fig. $6 \mathrm{Zr} / \mathrm{Hf}$ vs $\mathrm{Nb} / \mathrm{Ta}$ plot for JAIR samples (after Moayeed et al., 2008).

From the similarity of $\mathrm{Sr}-\mathrm{Nd}-\mathrm{Pb}$ isotopic signatures of the JAIR samples with those of the pristine Kerguelen plume basalts from the Kerguelen plateau and Broken ridge, Anil Kumar et al. (2007) suggested that JAIR (DAIR) and also Rajmahal flood basalts are direct Kerguelen plume-derived components. High-Ti contents of JAIR are unlike that of a source similar to MORB whereas phlogopite and carbonate, inferred in this study to be essential melting assemblages in the JAIR mantle source, are unstable at temperatures $\left(\sim 1480^{\circ} \mathrm{C}\right)$ of convecting (asthenosphere) mantle but persist only at the P-T conditions of cold, continental lithospheric mantle $\left(<1400^{\circ} \mathrm{C}\right)$. Subduction-related source heterogeneity invoked in this study also cannot be accounted by a plume model. Nd isotopes on JAIR samples give a $\mathrm{T}_{\mathrm{DM}}$ model ages of $\sim 900-1000 \mathrm{Ma}$ (Rock et al., 1992) andd suggests an enriched mantle source that has undergone long term enrichment of incompatible trace elements. ${ }^{15} \mathrm{~N}$ isotope compositions (7.09-7.56 \%) in some JAIR samples are interpreted to be recycled crustal $\mathrm{N}$ to the mantle (Jia et al., 2003). The crustal $\mathrm{N}$ signatures retained by the JAIR could well be the long term memories of ancient subduction experienced by their source region.

Based on the trace element signatures, $\mathrm{Nd}$ isotopes, ${ }^{15} \mathrm{~N}$ isotope compositions and available high pressure experimental data it is inferred that a substantial melt component of the JAIR was derived from the subcontinental lithospheric mantle (SCLM) and contribution of the convecting (asthenospheric) mantle is minimal. Kerguelen mantle plume is suggested to have only superimposed its isotopic signature on the JAIR mantle source regions and provided the heat but not a significant melt component.

\section{References}

Anil Kumar, A., Dayal, M. and Padmakumari, V.M., 2003, Kimberlite from Rajmahal magmatic province: $\mathrm{Sr}$ $\mathrm{Nd}-\mathrm{Pb}$ isotopic evidence for Kerguelen plume derived magmas, Geophys. Res. Lett., V.30, No. 20, 2053. doi: 10.1029/2003GL018462.

Jia, Y., Kerrich, R., Gupta, A.K., Fyfe, W.S., $2003 .{ }^{15} \mathrm{~N}-$ enriched Gondwana lamproites, eastern India: crustal $\mathrm{N}$ in mantle source. Earth and Planetary Science Letters, 215, 43-56.

Kent, R., Kelley, S.P., Pringle, M.S., 1998. Mineralogy and ${ }^{40} \mathrm{Ar} /{ }^{39} \mathrm{Ar}$ geochronology of orangeites (Group II kimberlites) from the Damodar valley, eastern India. Mineralogical Magazine, 63, 313-323.

Lefebvre, N., Kopylova, M., Kivi, K., 2005. Archaean calcalkaline lamprophyres of Wawa, Ontario, Canada: Unconventional diamondiferous volcaniclastic rocks. Precambrian Research 138, 57-87.

Le Maitre, R.W., 2002. Igneous rocks. A classification and glossary of terms. Recommendations of the international union of geological sciences subocmmission on the systematics of igneous rocks. Cambridge University Press, Cambridge, 236p.

Mitchell, R.H., 2007. Potassic rocks from the Gondwana coal fields of India: Closing Pandora's box of petrological confusion? Journal of Geological Society of India 69, 505-512.

Owen, J.P., 2007. Geochemistry of lamprophyres from the Western Alps, italy: implications for the origin of an enriched isotopic component in the Italian mantle. Contributions to Mineralogy and Petrology doi: 10.1007/s00410-007-0246-0.

Rock, N.M.S., Griffin, B.J., Edgar, A.D., Paul, D.K., Hergt,J.M., 1992. A spectrum of potentially dimondiferous lamproites and minettes from the Jharia coalfield, eastern India. Journal of Volcanology and Geothermal Research, 50, 55-83.

Sarkar, A., Paul, D.K., Balasubrahmaniyan, M.N., Sengupta, N.R., 1980. Lamprophyres from Indian Gondwanas: $\mathrm{K} / \mathrm{Ar}$ ages and chemistry. Journal of Geological Society of India, 21, 188-193.

Tappe, S., Foley, S.F., Jenner, G.A., Heaman, L.M., Kjarsgaard, B.A., Romer, R.L., Stracke, A., Joyce, N., Hoefs, J., 2006. Genesis of ultramafic lamprophyres and carbonatites at Aillik Bay, Labrador: a consequence of incipient beneath the North Atlantic craton. Journal of Petrology, 47, 12611315. 